\title{
Eurasian Arctic shelf hydrography: Exchange and residence time of southern Laptev Sea waters
}

\author{
D. Bauch ${ }^{\mathrm{a}, *}$, I. Dmitrenko ${ }^{\mathrm{a}}$, S. Kirillov ${ }^{\mathrm{c}}$, C. Wegner $^{\mathrm{a}}$, J. Hölemann ${ }^{\mathrm{b}}$, S. Pivovarov ${ }^{\mathrm{c}}$, L. Timokhov $^{\mathrm{c}}$, \\ H. Kassens ${ }^{\text {a }}$ \\ a Leibniz Institute of Marine Sciences, IFM-GEOMAR, Wischhofstr. 1-3, D-24148 Kiel, Germany \\ ${ }^{\mathrm{b}}$ Alfred Wegener Institute for Polar and Marine Research, Am alten Hafen 12, D-27568 Bremerhaven, Germany \\ c Arctic and Antarctic Research Institute, 199397 St. Petersburg, Russia
}

\section{A R T I C L E I N F O}

\section{Article history:}

Received 29 May 2008

Received in revised form

12 June 2009

Accepted 24 June 2009

Available online 1 July 2009

Keywords:

Polar oceanography

Continental shelves

Residence time

Halocline

Fast ice

Polynyas

\begin{abstract}
A B S T R A C T
The hydrography of the Laptev Sea is significantly influenced by river water and sea-ice processes, which are highly variable over the annual cycle. Despite of an estuarine structure the inner and outer shelf regions are decoupled at times as documented by the stability of a warm intermediate layer formed during summer below the Lena River plume. We demonstrate that a remnant of this warm layer is preserved below the fast ice until the end of winter, while only slightly farther to the north, offshore of the landfast ice in the polynya region, the pycnocline is eroded and no signature of this layer is found. The warm intermediate layer (WIL) formed during summer can be used as tracer for Laptev Sea shelf waters throughout the winter. Thereby, residence times of southern Laptev Sea waters can be estimated to be at least from summer to the end of winter/spring of the following year.
\end{abstract}

(c) 2009 Elsevier Ltd. All rights reserved.

\section{Introduction}

Variations and residence times of Laptev Sea waters may significantly influence the structure of the Arctic Ocean halocline (Johnson and Polyakov, 2001), which normally acts to isolate the sea-ice cover from the warm Atlantic-derived layer below. Although an average mean residence time for all Siberian shelves was derived as $3.5 \pm 2$ years (Schlosser et al., 1994), there is a clear lack of any detailed and more specific temporal information. A better knowledge of the residence time of waters on the shelf in causal linkage to the prevailing processes is of urgent importance in order to understand and predict both regional shelf dynamics and global environmental changes.

The vast Arctic shelves comprise about $\frac{1}{3}$ of the total Arctic Ocean area. While sea-ice and brine waters are produced during winter, the shelves are free of sea-ice during summer and sea-ice melt water is released together with fresh water from huge rivers. The Laptev Sea is one of the main production regions for Arctic sea-ice during winter (e.g. Zakharov, 1966) and large amounts of fresh water are received from the Lena River during summer. The seasonal hydrologic cycle explains about $25-75 \%$ of the entire salinity variability spectrum of the Siberian shelf hydrography

\footnotetext{
* Corresponding author.

E-mail address: dbauch@ifm-geomar.de (D. Bauch).
}

(Dmitrenko et al., 2008a). Inter-annual and decadal fresh water anomalies on the Laptev and East Siberian shelves are of the same order of magnitude as the annual fresh water export rate to the Arctic Ocean (Dmitrenko et al., 2008b).

In this study, the distribution and transformation of water masses in the Laptev Sea are evaluated on a seasonal basis using data collected between 1993 and 2003. It is shown that the feature of a warm intermediate layer (WIL) formed during summer season beneath the river plume can be used as a tracer for shelf waters throughout the winter. While we cannot quantitatively evaluate the various processes eroding the WIL, from the fact that the WIL is still preserved at some positions at the end of winter a lower estimate for the residence time is derived for the subsurface layer in the southern Laptev Sea.

\section{Material and methods}

Ship-based expeditions were carried out in early summer 1998 (Fig. 1a), in 1993, 1994, 1999, 2000 and 2003 during main summer (Fig. 1b) and during autumn 1995 (Fig. 1c). Data from winter/ spring expeditions were gained from the fast ice in the southern Laptev Sea and from the pack ice in the coastal polynya region in 1996 and 1999 (Fig. 1d). All CTD data have an accuracy of at least $0.02{ }^{\circ} \mathrm{C}$ in temperature and $0.02 \mathrm{mS} / \mathrm{cm}$ in conductivity. Salinity is reported on PSU scale without units according to SI convention. 

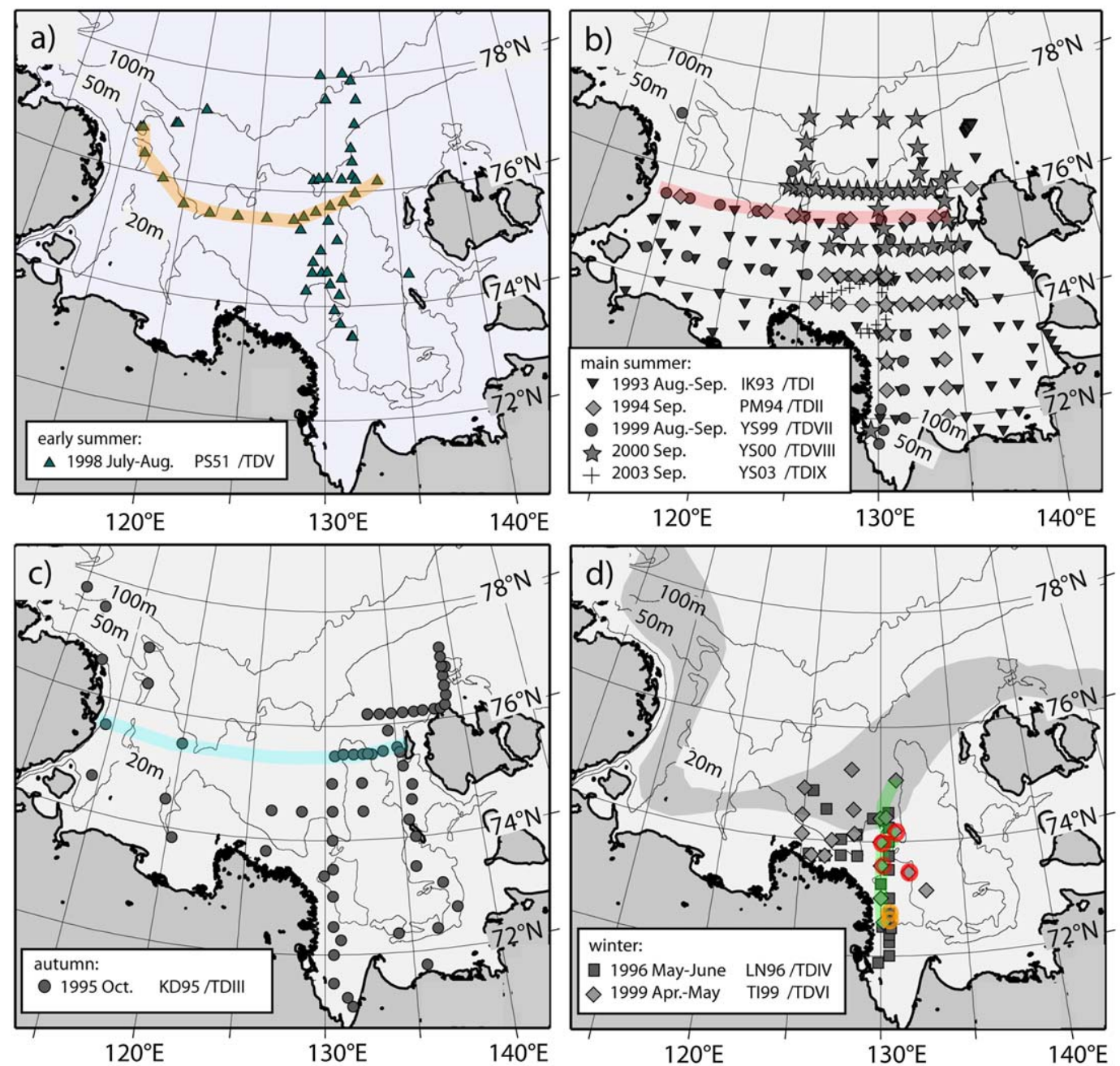

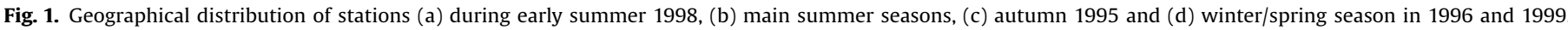

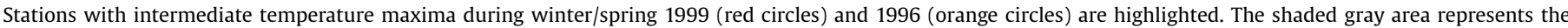

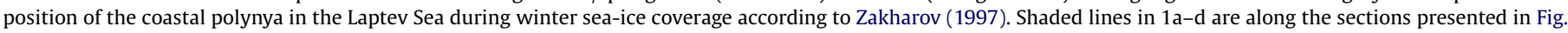

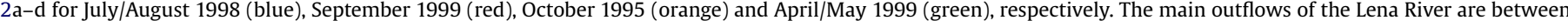
$72-73^{\circ} \mathrm{N}$ and $128^{\circ} \mathrm{E}$. (For interpretation of the references to colour in this figure legend, the reader is referred to the web version of this article.)

Further details on expeditions are given within Kassens et al. (1994, 1997), Kassens and Dmitrenko (1995), Dmitrenko et al. (1999, 2005b), Pivovarov et al. (1999).

\section{Hydrographic results}

The fast ice in the Laptev Sea generally breaks up in June at the time of the main river discharge, which is about 4-5 times higher than the annual mean discharge (e.g. Létolle et al., 1993). Sea-ice cover retreats mainly during July and August before it recurs in October (Bareiss and Görgen, 2005). Therefore, in early summer the surface waters are generally cold and within about $1{ }^{\circ} \mathrm{C}$ above the freezing point (Fig. 2a). In July-August 1998 sampling occurred directly after the peak in main river discharge and fast ice break-up, and at a time when sea-ice cover was regressing, but still covering $30-40 \%$ of the eastern Laptev Sea shelf area (Bareiss and Görgen, 2005). At this stage, only the low-salinity river plume showed a warm surface signal of up to $5{ }^{\circ} \mathrm{C}$ (Fig. 2a), since solar radiation had not yet warmed the surface layer of the investigated shelf area (Fig. 1a). A slight intermediate temperature maximum is, nevertheless, already visible at two stations below the river plume (compare Fig. 2a at about $120^{\circ} \mathrm{E}$ and $124^{\circ} \mathrm{E}$ and about $15 \mathrm{~m}$ water depth).

The main summer season is during September and due to extensive exposure to solar radiation there is an overall warm surface layer (Fig. 2b). The main outflow and dispersion of river runoff extends east of about $125-130^{\circ} \mathrm{E}$ with inter-annual differences mainly in geographical extension to the north (Dmitrenko et al., 2005a; Bauch et al., 2009). A WIL with temperatures of up to $5{ }^{\circ} \mathrm{C}$ is observed beneath the river plume (see Fig. 2b). This warm intermediate temperature layer at relatively high salinities (above 23) is seen in all our summer datasets (Fig. 1b) below the river plume and is generally found in the entire eastern Laptev Sea (Dmitrenko et al., 1999).

In autumn, surface waters are cooled again (Fig. 2c) and the shelf starts to freeze-up. A WIL of up to $3^{\circ} \mathrm{C}$ was preserved in autumn 1995 at depths between 15 and $20 \mathrm{~m}$ (Fig. 2c) at all stations east of about $127^{\circ} \mathrm{E}$ throughout the study area from 71 to $77^{\circ} \mathrm{N}$ (see Fig. 1c), while the surface layer was close to the freezing point.

In late winter, a remnant of this WIL is still preserved as documented in a local temperature maximum of up to about $-0.5^{\circ} \mathrm{C}$ and about $0.2-0.5^{\circ}$ higher than surrounding temperatures observed at about $10-13 \mathrm{~m}$ water depth and at a salinity of about 

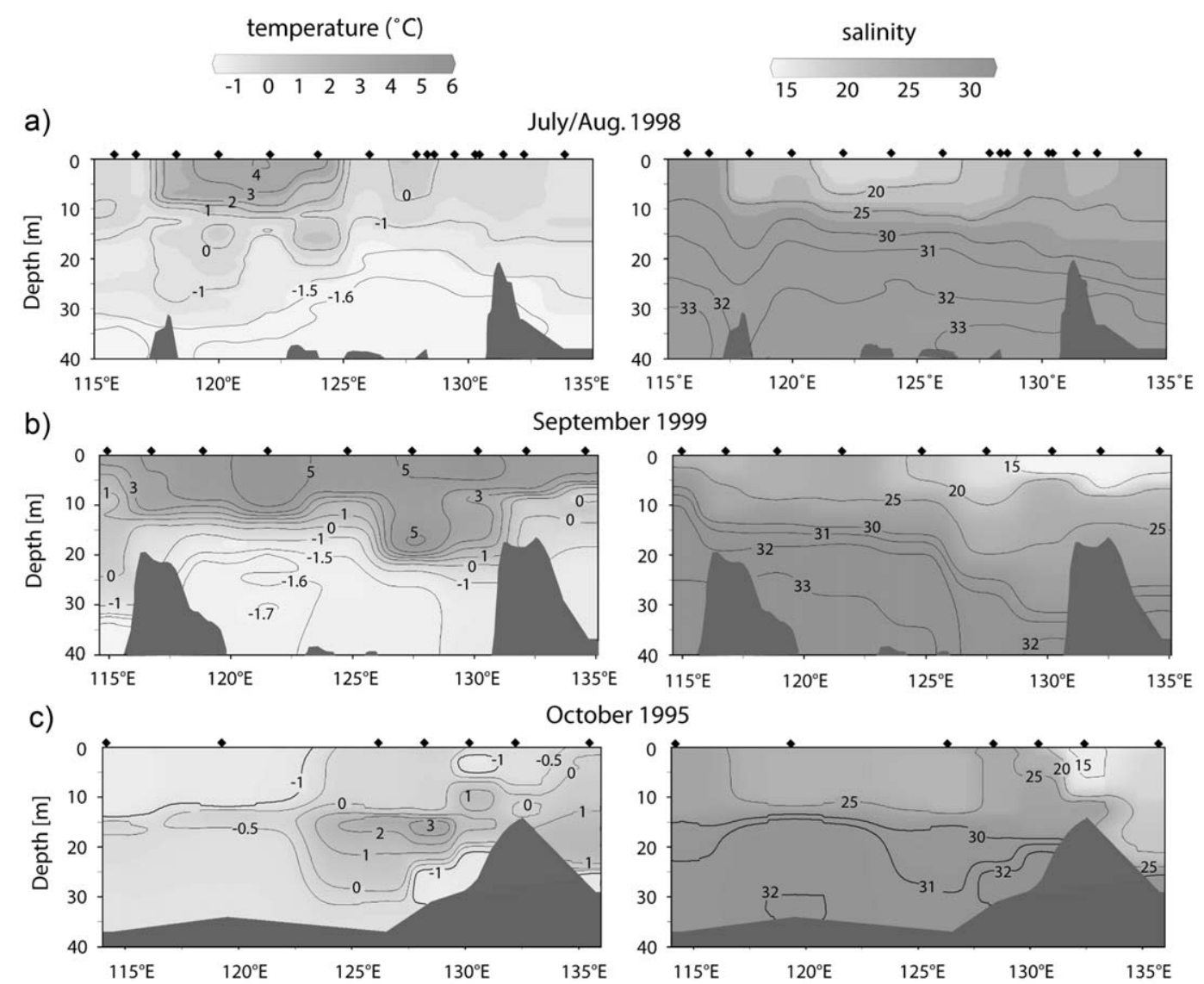

October 1995

d)

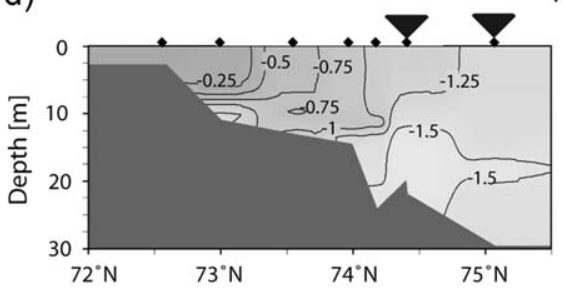

April/May 1999
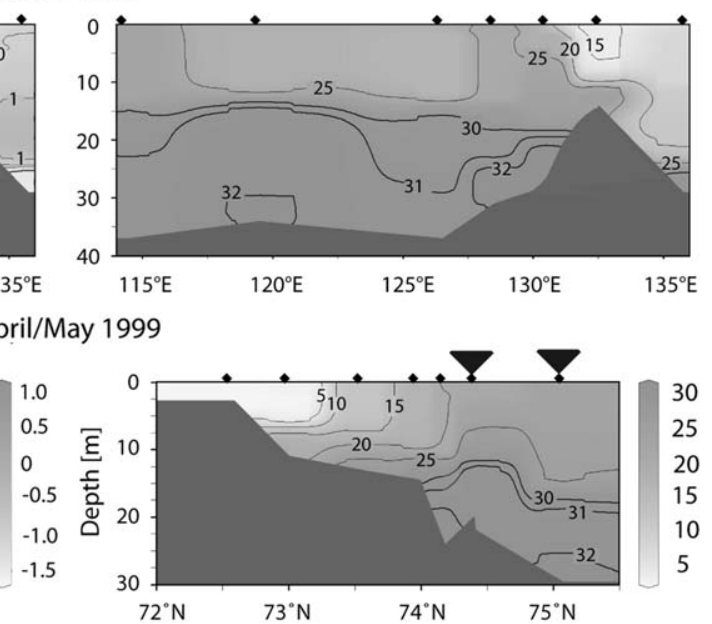

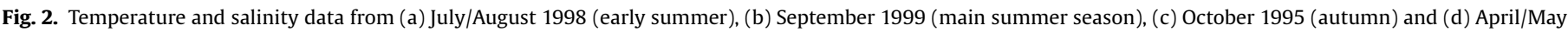

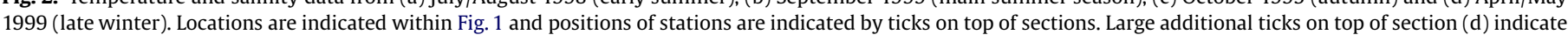
stations sampled within the polynya. Note different temperature and salinity scales and different section orientations for winter data in (d).

25 (Fig. 3b and $\mathrm{c}$ and compare Fig. $2 \mathrm{~d}$ at about $73.5-74.2^{\circ} \mathrm{N}$ ) at several stations below the fast ice in both April 1999 and May 1996 (Fig. 1d, red and orange highlighted stations, respectively). Although the water column remained stratified within the recurring polynya during the time of sampling (see Figs. $2 \mathrm{~d}$ and 3a) (Dmitrenko et al., 2005b) repeated sampling in winter 1999 revealed strong variations in the depth of the mixed surface layer (Fig. 3).

\section{Discussion}

Due to the strong seasonal variability in river runoff and seaice cover the hydrographic features of the Laptev Sea shelf are subject to strong seasonal changes (Fig. 2; note that density is in all seasons mainly determined by salinity and, therefore, well represented by salinity). The vertical stratification of the water column is most pronounced during summer, when Lena River discharge is enhanced and the surface temperatures are highest due to both the relatively warm river water and exposure to high solar radiation. As river runoff is largely reduced in winter, the surface layer with extremely low salinities is diminished accordingly during this time. Below the variable surface layer a halocline is nevertheless maintained throughout all seasons (Fig. 2a-d). At the position of the polynya repeated sampling documents a highly variable mixing depth in late winter, showing the permanent activity of the polynya in eroding the density stratification by mixing vs. replacement of waters by lateral advection (Fig. 3a) (Dmitrenko et al., 2005b). The evolution and stages of the polynya through the course of the winter have to be derived from further year-round measurements such as sea-floor observatories (e.g., Wegner et al., 2005).

A prominent feature of the hydrographic structure is the remnant of a WIL found throughout all seasons and formed during summer (Fig. 2b). During spring and summer the intensive river discharge to the Laptev Sea results in the formation of frontal systems between river and shelf waters (Dmitrenko et al., 1999). The isopycnals and isohalines are nearly parallel and run vertical down to the depth of the river plume and form a baroclinic front (see schematic sketch in Fig. 4a and compare Fig. 2a and b). Another type of front is formed below the river water, within the quasi-isothermal water layer directly below the baroclinic front. 


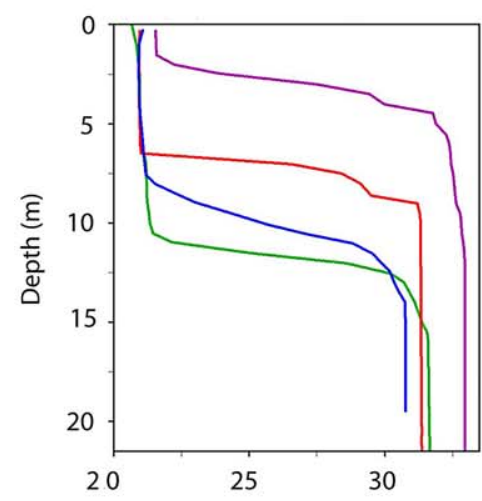

b

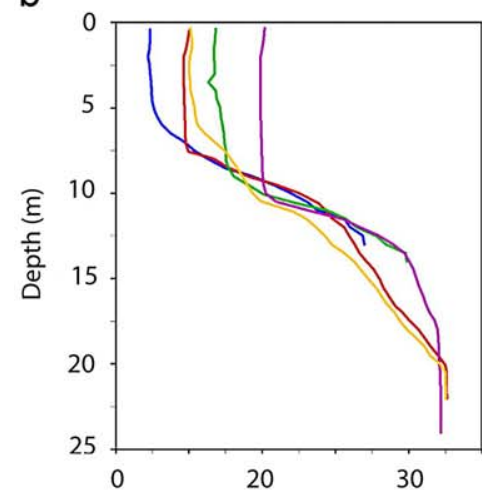

C

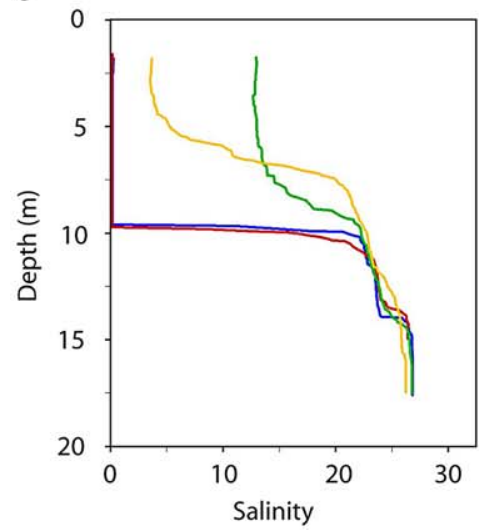

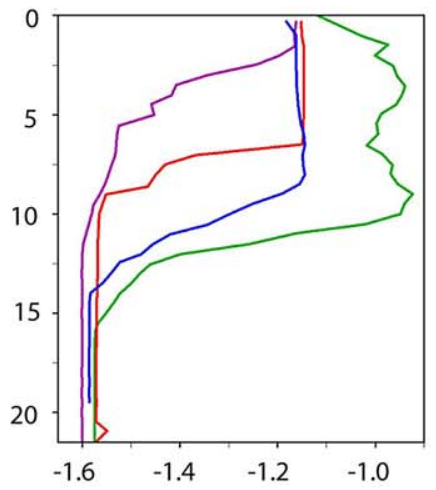

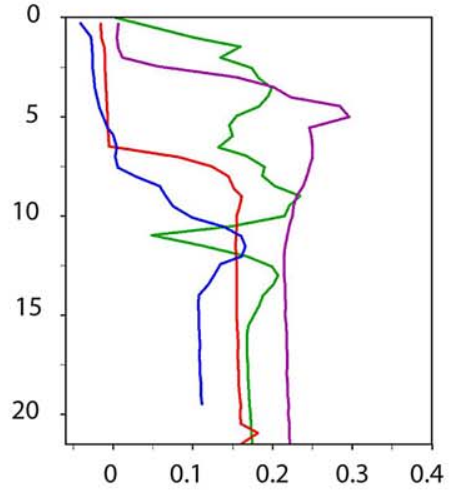

1999 fast ice stations
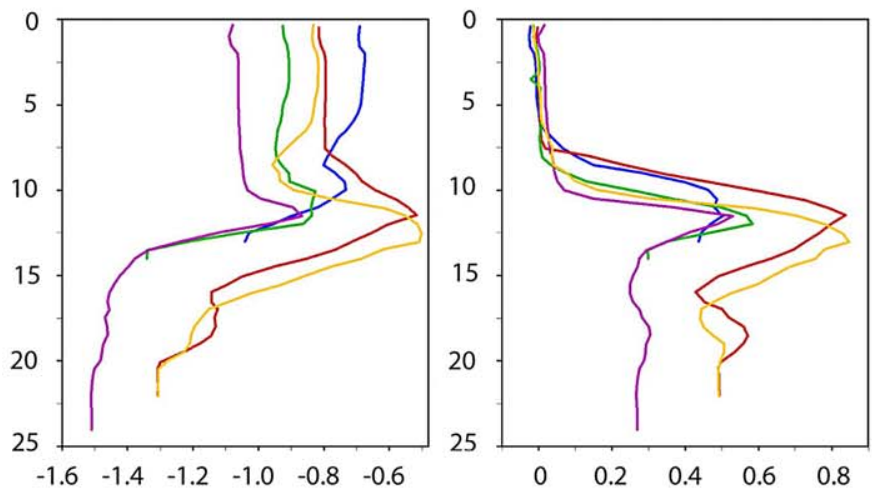

1996 fast ice stations
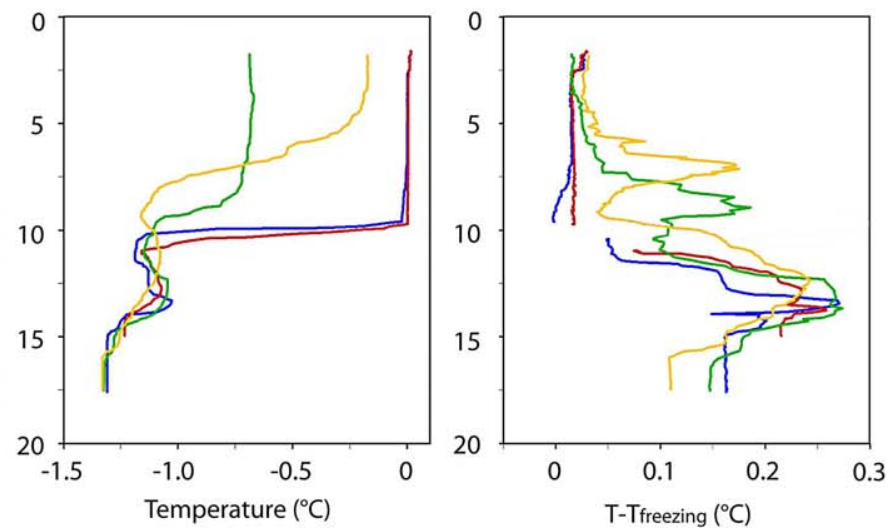

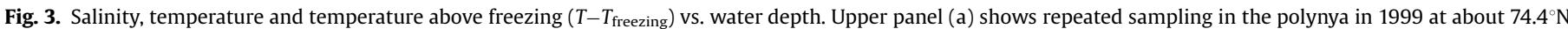

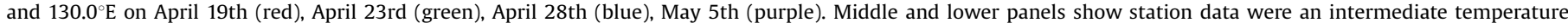

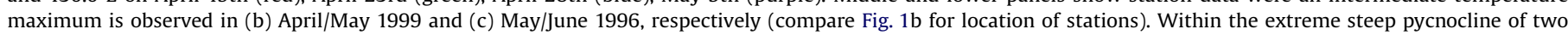

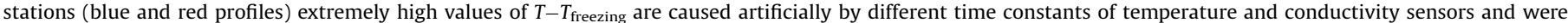
omitted within the plot. (For interpretation of the references to colour in this figure legend, the reader is referred to the web version of this article.)

The isopycnals and isohalines may intersect the isotherms here at an angel of up to $90^{\circ}$ (Golovin et al., 1995) and form a thermoclinic front (see Fig. 4a and compare Fig. 2a and b) The terms 'baroclinic front' and 'thermoclinic front' are used to indicate that isopycnic surfaces are intersected by equal pressure and temperature surfaces (Fedorov, 1991; Woods, 1980). Thus, the river runoff fronts of the Laptev Sea have a two layer structure. A seasonal pycnocline is maintained during summer by the penetrating river water and forms a baroclinic front, while below the main river water the front is thermoclinic and extends down to the main pycnocline. Since the WIL is observed in all of our summer datasets (Fig. 1b) the WIL is clearly a reoccurring and stable feature and not a transient phenomenon caused, e.g., by specific weather conditions during the time of sampling only. During autumn and winter the seasonal pycnocline is transformed when the river water is strongly reduced and surface waters are cold again out of the remaining river plume (see Fig. 4b and compare Fig. 2c and d). Salt is released to the water column in the fast ice region during initial ice growth and quasi-permanently by formation of sea-ice in the polynya region during winter. The WIL remains at intermediate depth within the pycnocline (see Fig. 4b and compare Figs. 2c and $3 \mathrm{~b}$ and c). There are two mechanisms which can explain the formation of the secondary thermoclinic discharge front and the formation of the warm intermediate layer (Dmitrenko et al., 1999). The simplest explanation is an isopycnic convergence of the solar-heated water beneath the river water. The less dense fresh water flows over the saline shelf water. This mechanism is probably most important 

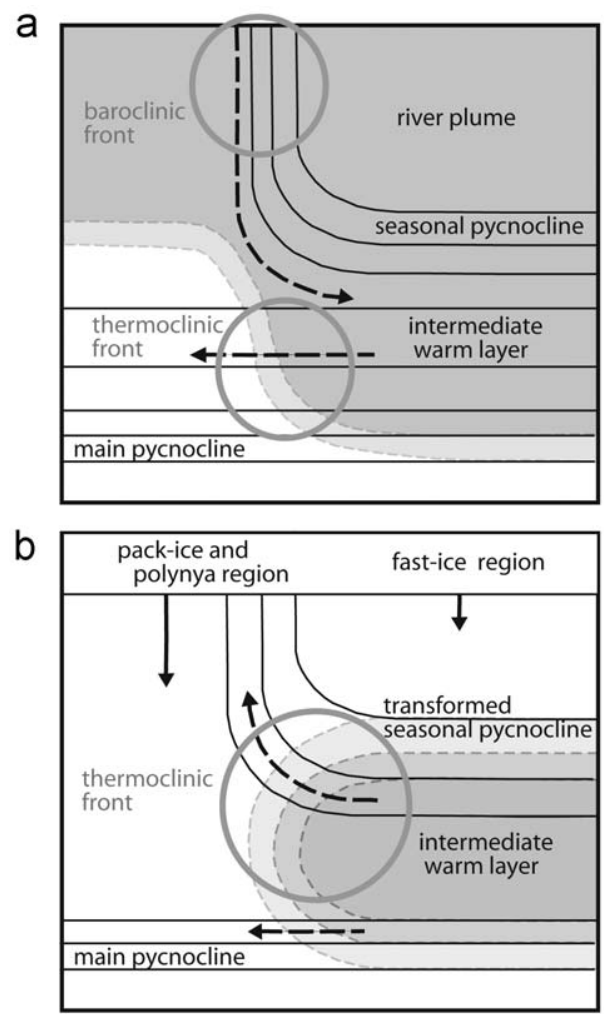

Fig. 4. Schematic sketch of the frontal systems at the river discharge fresh water lens during (a) summer and (b) winter. Positions of isopycnals and isohalines (solid black lines) and isotherms (stippled grey lines) are shown schematically. Since isopycnals and isohalines are in first-order identical no distinction was made Arrows depict heat fluxes (stippled arrows) and salt fluxes (solid arrows). Sketch was adjusted from Dmitrenko et al. (1999).

when the river discharge extends far northwards from the river mouth, e.g. during years when atmospheric forcing pushes the river plume offshore. Another mechanism is connected to the deflection of the thermocline under the influence of frontal convergence, when temperature does not influence the density field formation. This mechanism can be regarded as a passive admixture (Kuz'mina, 1980; Mac Vean and Woods, 1980) and may also occur within a short distance of the river mouth region and is, therefore, probably more important in years when atmospheric forcing pushes the river plume onshore and the main river front remains close to the coast. Both mechanisms form the secondary thermoclinic front beneath the upper baroclinic front (Dmitrenko et al., 1999).

The WIL is preserved during autumn (see Fig. 2c) and still in late winter an intermediate temperature maximum is recognized at several stations in the vicinity of the main Lena River outflow during both years of sampling (see stations highlighted in red and orange in Fig. 1d). Relatively, low silicate values within this layer (not shown, for more details see Pivovarov et al., 1999) indicate that this slight temperature maximum does not originate from high-silicate river water, which is the only contemporary heat source during winter, but is indeed a remnant from the WIL formed during the previous summer.

In addition to the strong seasonal changes (Fig. 2a-d) there are also considerable inter-annual variations within the Laptev Sea shelf hydrography, which can be correlated to the atmospheric forcing as described by a vorticity index (Dmitrenko et al., 2005a). The WIL is observed in our data during all seasons, which were obtained during different years with rather different atmospheric forcing, e.g. the atmospheric vorticity index is low in 1995 and high in 1998 and 1999. Nevertheless, all these years clearly show the occurrence of the WIL, which demonstrates that the feature of a WIL is in first order independent from inter-annual variations. In all five datasets from the main summer (Fig. 1b) the WIL is observed below the river plume and thereby, documents that the WIL is not caused by variable weather conditions during the sampling period, but is a stable feature of the Laptev Sea hydrography.

The heat content relative to freezing temperatures within the WIL is between about $3-5$ and $8-34 \mathrm{MJ} / \mathrm{m}^{2}$ at the end of winter in 1996 and 1999, respectively. At about the same positions (Fig. 1b) the heat content within the WIL was $60-150 \mathrm{MJ} / \mathrm{m}^{2}$ in autumn 1995. It is astonishing that part of the WIL is preserved from summer to the end of winter taken into account the various convective, advective and diffusive processes eroding the WIL. In the polynya region, lowering of pycnocline depth (Fig. 3a) documents the vigorous impact of convection triggered by the growth of sea-ice and consecutive expulsion of salt (Fig. 4b). The same time strong advection must be present in the polynya region that raises the depth of the pycnocline again (Fig. 3a). From the sparse data we cannot quantify the importance of convective vs. advective processes in the polynya region. We have even less observations below the fast ice, but have to assume that at least during the initial formation of the fast ice cover some convection must have also occurred here (see Fig. 4b). Advection of waters below the fast ice would further degrade the WIL since the polynya region, where the WIL is vigorously destroyed (see Fig. 4b), is in close proximity. Therefore, we assume that advection below the fast ice must be sufficiently small. Estimates considering vertical and lateral heat exchange at the level of molecular rate and turbulent heat exchange (Kirillov et al., 2003; Kirillov, 2007) indicate that a remnant of the summer WIL may be preserved until the end of winter, while at a shear of $15 \mathrm{~cm} / \mathrm{s}$ the turbulent heat exchange would be already too high and the WIL would completely disappear by March-April. While convective and advective processes are most prominent in the polynya region, these processes are obviously small enough below the fast ice in order to allow a small fraction of the WIL to remain still after 6-7 months of erosion.

We cannot quantify the processes of heat exchange, which erode the WIL during winter, but the observed remnants of the WIL in April/May 1999 and May/June 1996 demonstrate that the various processes of heat exchange are not efficient enough to transport all the heat stored in the intermediate layer towards the sea surface at these positions. Thereby, we assume that the role of advection and convection below the fast ice is small relative to local processes. Our data indicates a nearly stagnant water column below the fast ice as is also documented within the sea-ice structure (Eicken et al., 2005) and in accordance with decreasing oxygen concentration and increasing phosphate concentrations (not shown) from top to bottom during winter. Only slightly farther north, within the polynya, the upper layer is mixed (Fig. 3 upper panel) and convective mixing here is likely to occur (Dmitrenko et al., 2005b). Thus, no remnant of the WIL is observed here accordingly.

\section{Conclusions}

Even though subject to strong seasonal changes our detailed datasets from the Laptev Sea shelf show a stratified structure throughout all seasons. Winter hydrographic data show a stratified water column below the fast ice as well as at the position of the polynya. Within the polynya the depth of the upper mixed layer varies strongly in time indicating the potential formation of cold and saline bottom water masses by sea-ice formation. Below the fast ice the water structure remains stable 
throughout the winter, leaving a remnant of the WIL formed at the salinity front of the main river discharge during summer. This evidence indicates a decoupling of the inner and middle shelf region in terms of lateral exchange during winter. The conservation of the WIL south of the polynya documents that the residence time of shelf waters below the pycnocline in the southern Laptev Sea inner shelf is at least one seasonal cycle from summer to late winter/spring season the following year.

The mean residence time in linkage with shelf processes is important in order to understand the hydrography and climatic changes on the Laptev Sea shelf. Due to the influence of the Laptev Sea on the hydrography of the Arctic Ocean halocline there might also be regional implications and future modeling studies are necessary to estimate the extent of this influence. In this respect, it is also significant that the WIL can be generally used as a tracer for the subsurface waters in the southern Laptev Sea throughout the winter.

\section{Acknowledgments}

We thank all members of the project "System Laptev Sea". DB acknowledges funds through the DFG Grant SP 526/3 and ID through the BMBF 03G0639A project. SK acknowledges funding through the BMBF project "Otto-Schmidt-Laboratory for Polar and Marine Sciences" (03PL038A). CW acknowledges funds through the DFG Grant WE 4206/1-1.

\section{References}

Bareiss, J., Görgen, K., 2005. Spatial and temporal variability of sea ice in the Laptev Sea: analyses and review of satellite passive-microwave data and model results, 1979-2002. Global and Planetary Change 48, 28-54, doi:10.1016/ j.gloplacha.2004.12.004.

Bauch, D., Dmitrenko, I.A., Wegner, C., Holemann, J., Kirillov, S.A., Timokhov, L.A., Kassens, H., 2009. Exchange of Laptev Sea and Arctic halocline waters in response to atmospheric forcing. Journal of Geophysical Research 114, C05008, doi:10.1029/2008JC005062.

Dmitrenko, I., Golovin, P., Gribanov, V., Kassens, H., 1999. Oceanographic causes for transarctic ice transport of river discharge. In: Kassens, H., Bauch, H.A., Dmitrenko, I., Eicken, H., Hubberten, H.-W., Melles, M., Thiede, J., Timokhov, L. (Eds.), Land-Ocean Systems in the Siberian Arctic: Dynamics and History. Springer, Berlin, pp. 73-92.

Dmitrenko, I.A., Kirillov, S.A., Eicken, H., Markova, N., 2005a. Wind-driven summer surface hydrography of the eastern Siberian shelf. Geophysical Research Letters 32, L14613, doi:10.1029/2005GL023022.

Dmitrenko, I.A., Tyshko, K.N., Kirillov, S.A., Eicken, H., Hölemann, J.A., Kassens, H., 2005b. Impact of flaw polynyas on the hydrography of the Laptev Sea. Global and Planetary Change 48, 9-27, doi:10.1016/j.gloplacha.2004.12.016.

Dmitrenko, I.A., Kirillov, S.A., Tremblay, L.B., Bauch, D., Makhotin, M., 2008a. Effects of atmospheric vorticity on the seasonal hydrographic cycle over the eastern Siberian shelf. Geophysical Research Letters 35, L03619, doi:10.1029/ 2007GL032739.
Dmitrenko, I.A., Kirillov, S.A., Tremblay, L.B., 2008b. The long-term and interannua variability of summer fresh water storage over the eastern Siberian shelf: implication for climatic change. Journal of Geophysical Research 113, C03007, doi:10.1029/2007JC004304.

Eicken, H., Dmitrenko, I., Tyshko, K., Darovskikh, A., Dierking, W., Blahak, U., Groves, J., Kassens, H., 2005. Zonation of the Laptev Sea landfast ice cover and its importance in a frozen estuary. Global and Planetary Change 48, 55-83, doi:10.1016/j.gloplacha.2004.12.005.

Fedorov, K.N., 1991. About Thermohaline Characteristics of Oceanic Fronts (in Russian), In: Fedorov, K.N. Izbrannye Trudy po Fizicheskoi Okeanologii, Gidrometeoizdat, Leningrad, 106-111.

Golovin, P., Gribanov, V, Dmitrenko, I., 1995. Macro- and Mesoscale Hydrographic Structure of the outfloe zone of the Lena River Water to the Laptev sea. In: Kassens, H., Piepenburg, D., Thiede, J., Timokhov, L., Hubberten, H.-W. Priamikov, S. (Eds.), Russian-German Cooperation: Laptev Sea System. Ber Polarforschung, Bremerhaven, pp. 99-106.

Johnson, M.A., Polyakov, I.V., 2001. The Laptev Sea as a source for recent arctic ocean salinity changes. Geophysical Research Lettes 28 (10), 2017-2020.

Kirillov, S.A., Dmitrenko, I.A., Darovskih, A.N., Eicken, H., 2003. Influence of shear instability of internal waves on processes of the vertical turbulent heat exchange on the Laptev Sea shelf. Doklady Earth Sciences 390 (4), 533-537.

Kirillov, S., 2007. Spatial variations in sea-ice formation-onset in the Laptev Sea as a consequence of the vertical heat fluxes caused by internal waves overturning. Polarforschung 76 (3), 119-123.

Kassens, H., Karpy, V., Shipboard Scientific Party (Eds.), 1994. Cruise report of the Expedition TRANSDRIFT I in the Laptev-Sea, Reports on Polar Research, 151, pp. 168.

Kassens, H., Dmitrenko, I., 1995. The TRANSDRIFT II Expedition to the Laptev Sea. In: Kassens, H. (Ed.), Laptev Sea System: Expeditions in 1994. Reports on Polar Research, 182, pp. 1-180.

Kassens, H., Dmitrenko, I., Timokhov, L., Thiede, J., 1997. The TRANSDRIFT III Expedition: Freeze-Up Studies in the Laptev Sea. In: Kassens, H. (Ed.) Laptev Sea System: Expeditions in 1995. Reports on Polar Research, 248, pp. 1-192.

Kuz'mina, N.P., 1980. About Oceanic Frontigenesis (in Russian). Izv. Akad. Nauk SSSR, Fizika atmosphery i okeana 16 (10), 1082-1090.

Létolle, R., Martin, J., Thomas, A., Gordeev, V., Gusarova, S., Sidorov, I., 1993. ${ }^{18} \mathrm{O}$ abundance and dissolved silicate in the Lena delta and Laptev Sea (Russia). Marine Chemistry 43, 47-64.

Mac Vean, M.K., Woods, J.D., 1980. Redistribution of scalars during upper ocean frontogenesis. Quarterly Journal of Royal Meteorological Society 106 (448) 293-311.

Pivovarov, S., Hölemann, J., Kassens, H., Antonow, M., Dmitrenko, I., 1999. Dissolved oxygen, silicon, phosphorous and suspended matter concentrations during the spring breakup of the Lena River. In: Kassens, H., Bauch, H.A., Dmitrenko, I. Eicken, H., Hubberten, H.-W., Melles, M., Thiede, J., Timokhov, L. (Eds.), Land-Ocean Systems in the Siberian Arctic: Dynamics and History. Springer, Berlin, pp. 251-264.

Schlosser, P., Bauch, D., Bönisch, G., Fairbanks, R.F. 1994 Arctic river-runoff: mean residence time on the shelves and in the halocline. Deep-Sea Resaerch I 41 (7), 1053-1068.

Wegner, C., Hölemann, J.A., Dmitrenko, I., Kirillov, S.A., Kassens, H., 2005. Seasonal variations in arctic sediment dynamics-evidence from 1-year records in the Laptev Sea (Siberian arctic). Global and Planetary Change 48, 126-140, doi:10.1016/j.gloplacha.2004.12.009.

Woods, J.D., 1980. The generation of thermohaline finestructure at fronts in the ocean. Ocean Modelling 32, 1-4.

Zakharov, V.F., 1966. The role of flaw leads off the edge of fast ice in the hydrological and ice regime of the Laptev Sea. Oceanology 6 (1), 815-821 (in Russian).

Zakharov, V.F., 1997. Sea ice in the Climate System. Arctic Climate System Study, World Climate Research Programme. World Meteorological Organization, Geneva (WMO/TD 782, p. 80). 